Syntax Literate : Jurnal Ilmiah Indonesia p-ISSN: 2541-0849

e-ISSN : 2548-1398

Vol. 5, No. 4 April 2020

\title{
UPAYA PENINGKATAN KESEHATAN JIWA MASYARAKAT MELALUI PEMBENTUKAN DESA SIAGA SEHAT JIWA (DSSJ)
}

\section{Reni Nuryani, Sri Wulan Lindasari dan Popi Sopiah}

Prodi Keperawatan, Universitas Pendidikan Indonesia Kampus di Sumedang

Email:reni.nuryani@upi.edu, sriwulan@upi.edu dan popisopiah@upi.edu

\section{Abstrak}

This activity is motivated by the lack of public awareness about the importance of mental health as indicated by the presence of mental patients who have not taken medication, and there are clients who do not take regular treatment at the Public health center, so occur to relapse and the discovery of client behavior that threatens the safety and comfort of the community. Efforts to handle it by providing community-based mental health nursing services based on effort of promotive, preventive, curative and rehabilitative with the establishment of the ready village for mental healthy to empower the community towards independence in the form of public awareness willing and able to prevent and overcome the mental health problems of its citizens. This activity aims to form the ready village for mental healthy, the detection of community mental health conditions, conduct mental health cadre training to empower community members, is done training cadre of mental health empower public, and improvement kowledge and awareness of the citizens about the importance of mental health. The method is done by using act review to complete problem in citizens about problem of mental health. What resulted was the formation of the ready village for mental healthy, an increase in the knowledge and ability of mental health cadres in detection after 5 mentions, and the detection results showed an increase in the number of ODGJ by 19 and nearly half the risk group had hypertension.

Keywords: the ready village for mental healthy, mental health, cadre of mental health

Abstrak

Kegiatan ini dilatarbelakangi oleh kurangnya kesadaran masyarakat tentang pentingnya kesehatan jiwa yang ditandai dengan adanya klien gangguan jiwa yang belum melakukan pengobatan, dan ada klien yang tidak melakukan pengobatan secara teratur ke puskesmas sehingga terjadi kekambuhan serta ditemukannya perilaku klien yang mengancam keamanan dan kenyamanan warga masyarakat. Upaya penanganannya dengan memberikan pelayanan keperawatan kesehatan jiwa berbasis masyarakat meliputi upaya promotif, preventif, kuratif dan rehabilitative dengan pembentukan Desa Siaga Sehat Jiwa guna untuk memberdayakan masyarakat menuju kemandirian berupa masyarakat sadar, mau dan mampu mencegah serta mengatasi masalah kesehatan jiwa warganya. Kegiatan ini bertujuan untuk terbentuknya Desa Siaga Sehat Jiwa, terdeteksinya kondisi kesehatan jiwa masyarakat, dilakukannya pelatihan kader kesehatan jiwa untuk memberdayakan warga masyarakat, dan meningkatkan pengetahuan dan kesadaran 
warga tentang pentinganya kesehatan jiwa. Metodologi dilakukan dengan menggunakan kaji tindak untuk menyelesaikan permasalahan di masyarakat tentang masalah kesehatan jiwa. Adapun yang dihasilkan adalah terbentuknya Desa Siaga Sehat Jiwa, adanya peningkatan pengetahuan dan kemampuan kader kesehatan jiwa dalam deteksi setelah 5 kali pendampingan, dan hasil deteksi menunjukan peningkatan jumlah ODGJ sebesar 19 dan hampir setengahnya kelompok risiko mengalami hipertensi.

Kata kunci: Desa Siaga Sehat Jiwa, Kesehatan jiwa, Kader Kesehatan Jiwa

\section{Pendahuluan}

Berdasarkan (Kesehatan, 2013) bahwa prevalensi gangguan jiwa berat pada penduduk di Indonesia mencapai 1,7 per mil, dan di Jawa Barat mencapai 0,16\%, sedangkan prevalensi gangguan mental emosional pada penduduk Indonesia sebesar 6,0\% dan Jawa Barat 9,3\%. Prevalensi masalah kesehatan jiwa pada penduduk di Kabupaten Sumedang yaitu gangguan mental emosional sebesar 7,5\% (97500 orang) dan prevalensi gangguan jiwa berat $0,11 \%$ sekitar 1430 orang dari jumlah penduduk 1,3 juta orang. Hal tersebut menunjukan bahwa Kabupaten Sumedang memiliki prevalensi gangguan mental emosional yang melebihi prevalensi Indonesia sehingga dapat menjadi resiko masalah kesehatan jiwa yang perlu ditangani supaya tidak berdampak menjadi gangguan jiwa. Menurut data dari Program Kesehatan Jiwa Dinas Kesehatan Kabupaten Sumedang Tahun 2018 bahwa prevalensi gangguan jiwa di wilayah Puskesmas Cimalaka termasuk 10 besar dan Desa Mandalaherang merupakan desa yang paling banyak klien gangguan jiwa yang belum mendapatkan pengobatan (Cimalaka, 2018), hal ini sesuai teori bahwa masyarakat pedesaan memiliki resiko yang tinggi tentang kesehatan jiwa, karena masyarakat mengganggap hal biasa yang terjadi dan masyarakat pedesaan mencari pelayanan kesehatan jiwa pada tahap akhir (Stuart, 2014).

Hasil studi lapangan bahwa klien gangguan jiwa di Desa Mandalaherang ada yang belum mendapatkan pengobatan dan ada juga tidak melakukan pengobatan secara teratur sehingga sering terjadi kekambuhan, selain itu menurut penuturan warga bahwa klien yang mengalami gangguan jiwa sering ngamuk dan meresahkan masyarakat, warga masyarakat masih menganggap bahwa gangguan jiwa tersebut merupakan penyakit kutukan dan merupakan penyakit yang memalukan bagi keluarga sehingga masyarakat sering kali merasa terancam keamanan dan kenyamanannya, sering mengucilkan serta mengabaikan klien gangguan jiwa yang ada di lingkungannya hal ini menunjukan bahwa kurangnya pengetahuan masyarakat tentang kesehatan jiwa dan kurangnya kesadaran warga masyarakat dalam merawat anggota keluarganya yang mengalami gangguan jiwa. Petugas pemegang program kesehatan jiwa Puskesmas Cimalaka menyatakan bahwa sudah melakukan kunjungan rumah kepada klien dan keluarga yang mengalami gangguan jiwa tetapi belum teratur karena mengalami kendala diantaranya jumlah klien yang meningkat sehingga sulitnya mengatur waktu untuk kunjungan rumah dan kurangnya partisipasi masyarakat dalam mendukung kegiatan mengatasi masalah kesehatan jiwa. 
Gangguan jiwa merupakan masalah kesehatan jiwa berat yang dapat mengganggu fungsi jiwa yaitu terganggunya kognitif, afektif dan hambatan fungsi sosialnya sehingga tidak mampu melakukan akitivitas sehari-hari (Budi Anna Keliat, Helena, \& Nurhaeni, 2011). Gejala gangguan jiwa yang mengancam keluarga dan lingkungan sekitar, mengakibatkan beban secara materi dan moril bagi keluarga dan akan bertambah berat dengan adanya stigma dan penolakan dari lingkungan sehingga keluarga tidak mampu memenuhi hak klien gangguan jiwa (Stuart, 2014). Selain beban pada keluarga klien dengan gangguan jiwa dapat menimbulkan beban bagi pemerintah dan masyarakat karena produktivitas menurun sehingga berdampak pada biaya pengobatan (Townsend \& Morgan, 2017).

Upaya penanganan pada klien dengan masalah kesehatan jiwa di masyarakat yaitu dengan memberikan suatu program pelayanan keperawatan. Secara substansial mutu pelayanan yang diberikan kepada masyarakat tergantung pada manajemen dalam organisasi sehingga mampu mencapai tujuan organisasi dalam memberikan pelayanan yang baik kepada masyarakat. Pelayanan yang baik kepada masyarakat sangat ditentukan oleh peranan sumber daya manusia sebagai pelaku utama yang sangat menentukan dalam poses pencapaian tujuan organisasi (Pujiastuti, 2017).

Kesehatan jiwa berbasis masyarakat yang tidak hanya berfokus pada upaya kuratif dan rehabilitatif tetapi juga terdapat upaya promosi, dan preventif dengan bentuk pendekatan Community Mental Health Nursing yang berfokus pada masyarakat yang sehat, dan resiko yaitu masyarakat yang rentan terhadap stress dan klien dengan gangguan jiwa dalam tahap pemulihan serta pencegahan kekambuhan secara komprehensif, holistik dan paripurna sehingga masyarakat yang pernah mengalami gangguan jiwa juga dapat hidup sukses serta produktif di masyarakat (Budi Anna Keliat, Helena, et al., 2011).

Salah satu kegiatan Community Mental Health Nursing adalah pembentukan Desa Siaga Sehat Jiwa (DSSJ) sebagai program pemberdayaan masyarakat menuju kemandirian berupa masyarakat sadar, mau dan mampu mencegah serta mengatasi masalah kesehatan jiwa warganya agar masyarakat ikut berperan serta dalam mendeteksi pasien gangguan jiwa yang belum terdeteksi, dan membantu pemulihan pasien yang telah dirawat di rumah sakit, serta siaga terhadap munculnya masalah kesehatan jiwa di masyarakat (Budi Anna Keliat, Panjaitan, \& Riasmini, 2011). Pembentukan Desa Siaga Sehat Jiwa tersebut merupakan pemberdayaan masyarakat yaitu dari dan untuk masyarakat dalam meningkatkan kesehatan jiwanya.

Berdasarkan hasil penelitian, bahwa pelayanan Desa Siaga Sehat Jiwa mampu meningkatkan kemandirian pasien dalam perawatan dirinya dalam aktivitas sehari-hari, aktivitas sosial, dan pengobatan (Fitri, 2007). Selain itu hasil penelitian tentang penerapan Desa Siaga Sehat Jiwa di Aceh menunjukan bahwa pasien dengan gangguan jiwa memiliki peluang $50 \%$ untuk pulih yaitu $25 \%$ pasien dapat sembuh kembali dan 25\% dapat mandiri, 25\% pasien memerlukan bantuan dan 25\% pasien bergantung pada orang lain (Budi Anna Keliat, Helena, et al., 2011). Pelaksanaan kegiatan Community Mental Health Nursing juga tidak terlepas dari peran serta warga masyarakat dan 
pemberdayaan kader dalam mendukung keberhasilannya. Hal ini terbukti dari hasil penelitian oleh (Junardi, Keliat, \& Daulima, 2017) yang menyatakan bahwa pelaksanaan IC CMHN kurang baik dapat dilihat dari kegiatan pelaksnaan pemberdayaan kader, penerapan kemitraan lintas sektor dan penerapan asuhan keperawatan jiwa masyarakat yang masih kurang.

Pembentukan Desa Siaga Sehat Jiwa dipandang perlu guna meningkatkan kesehatan jiwa masyarakat karena berawal dari kegiatan kemandirian masyarakat dalam upaya pelayanan kesehatan jiwanya dan untuk masyarakatnya itu sendiri. Menurut pemaparan Kepala Puskesmas bahwa Puskesmas Cimalaka memiliki potensi dan menjadi peluang untuk memotivasi dan melibatkan peran serta warganya dalam pembentukan Desa Siaga Sehat Jiwa guna meningkatkan pengetahuan dan kesadaran warga masyarakat dalam meningkatkan kesehatan jiwa masyaraka tmengingat adanya permasalahan, dan belum adanya Desa Siaga Sehat Jiwa serta sudah melakukan pembentukan TPKJM (Tim Penanggulangan Kesehatan Jiwa Masyarakat) Kecamatan Cimalaka pada bulan Pebruari 2019 termasuk Kepala Desa Mandalaherang sebagai anggotanya serta Desa Mandalaherang sudah menjadi Desa Siaga tetapi masih berfokus pada masalah kesehatan secara umum belum berfokus pada masalah kesehatan jiwa.

\section{Metode Penelitian}

Metode yang digunakan dalam menyelesaikan masalah ini dengan metode kaji tindak yaitu memberikan perlakuan untuk mengatasi permasalahan yang muncul di masyarakat dengan bentuk aplikasi pemberdayaan masyarakat (Alwasilah \& Setiawan, 2011). Beberapa jenis metode kaji tindak yang sudah dilakukan dengan pemberdayaan masyarakat yaitu sosialisasi dan pembentukan Desa Siaga Sehat Jiwa, pembentukan Kader Kesehatan Jiwa, pelatihan Kader Kesehatan Jiwa, dan Deteksi Kesehatan Jiwa keluarga. Tahap awal kegiatan ini dengan mengidentifikasi dan mengkaji permasalahan dilapangan yang dilanjutkan dengan koordinasi dengan pihak Puskesmas Cimalaka menjalin kemitraan dan kerjasama untuk mengembangkan Desa Binaan dalam meningkatkan kesehatan jiwa untuk membentuk Desa Siaga Sehat Jiwa.

Selanjutnya pelaksanaan sosialisasi dan pembentukan Desa Siaga Sehat Jiwa di Desa Mandalaherang serta pembentukan kader kesehatan jiwa melalui musyawarah masyarakat Desa dan proses seleksi, yang dihadiri oleh warga masyarakat yang terdiri dari kader, tokoh masyarakat, tokoh agama, aparat pemerintahan desa, bidan desa, dan Kepala Puskesmas. Setelah itu dilanjutkan dengan melakukan pelatihan kader kesehatan jiwa untuk pembekalan ilmu pengetahuan dan kemampuan kader dalam melaksanakan peran dan fungsinya di Desa Siaga Sehat Jiwa sebagai bentuk pemberdayaan masyarakat dalam meningkatkan kesehatan jiwa warganya. Pada pelatihan ini kader kesehatan jiwa diberikan materi tentang desa siaga sehat jiwa, masalah kesehatan jiwa, deteksi kesehatan jiwa sehingga dapat mengelompokan keluarga sesuai kategori sehat, risiko dan gangguan jiwa, cara menggerakan masyarakat untuk mengikuti penyuluhan, kunjungan rumah, rujukan kasus dan cara pendokumentaian.Pengetahuan dan 
kemampuan kader diukur dengan melakukan pre dan post tes dengan menggunakan instrument pertanyaan yang sudah baku dalam pengembangan desa siaga sehat jiwa (B A Keliat, Panjaitan, Riasmini, \& Mardella, 2010).

Metode berikutnya yaitu melakukan deteksi kesehatan jiwa keluarga yang merupakan kegiatan sebagai aplikasi dari pelatihan kader kesehatan jiwa untuk mengetahui kondisi kesehatan keluarga dengan melakukan kunjungan rumah sehingga dapat teridentifikasi keluargas sehat, risiko dan gangguan jiwa. Setelah pelatihan, kader mendapat pendampingan sebanyak 5 kali sebelum melakukan deteksi secara mandiri. Hasil deteksi ini dapat memberikan informasi tentang keehatan jiwa keluarga sehingga dapat menentukan rencana tindakan selanjutnya dan menjadi data dasar bagi pemerintah dalam menentukan kebijakan khusussnya Puskesmas Cimalaka. Kegiatan deteksi kesehatan jiwa keluarga menggunakan instrumen yaitu format isin hasil deteksi kesehatan jiwa dan buku pedoman deteksi kesehatan jiwa bagi kader yang dimodifikasi dari panduan kader kesehatan jiwa yang dikembangkan oleh (Budi Anna Keliat, Helena, et al., 2011).

\section{Hasil dan Pembahasan}

Hasil dan pembahasan dapat diuraikan sesuai kegiatan pada penelitian ini adalah sebagai berikut:

\section{Sosialisasi dan Pembentukan Desa Siaga Sehat Jiwa}

Pelaksanaan sosialisasi dan pembentukan Desa Siaga Sehat Jiwa di Desa Mandalaherang melalui musyawarah masyarakat Desa, kegiatan sosialisasi dan pembentukan ini dilaksanakan pada tanggal 2 September 2019 bertempat di aula Desa Mandalaherang, yang dihadiri oleh 60 orang warga masyarakat yang terdiri dari aparat pemerintahan Desa (Ketua RT, RW, Kepala Dusun), tokoh masyarakat, tokoh agama, BPD, kader, Karang Taruna, Kepala Desa dan Kepala Puskesmas Cimalaka. Masyarakat sangat antusias mengikuti kegiatan sosialisasi sampai selesai dengan diakhiri pembentukan DSSJ meskipun kegiatan dilakukan dimalam hari dan banyak warga yang bersedia menjadi kader kesehatan jiwa. Hasil kegiatan ini tersusun struktur organisasi kepengurusan Desa Siaga Sehat Jiwa yang terdiri dari Penasehat, Ketua, Bendahara, Sekretaris koordinator tiap RW dan anggota untuk masing-masing RW yang tertuang dalam Surat Keputusan Kepala Desa.

Pembentukan Desa Siaga Sehat Jiwa ini diperkuat oleh teori (BA Keliat et al., 2010) bahwa Desa Siaga Sehat Jiwa merupakan bentuk pelayanan keperawatan kesehatan jiwa masyarakat dengan memberdayakan keluarga dan masyarakat untuk meningkatkan kesehatan jiwa masyarakat, masyarakat dapat melakukan deteksi pasien gangguan jiwa, memelihara yang sehat biar tetap sehat, yang mengalami masalah kesehatan jiwa (ODMK) cepat pulih dan tidak terjadi gangguan jiwa, serta yang gangguan jiwa dapat hidup mandiri dan produktif. 


\section{Pembentukan Kader Kesehatan Jiwa}

Pembentukan Kader Kesehatan Jiwa ini dilakukan dengan proses seleksi dan rekrutmen kader kesehatan jiwa sesuai kriteria yaitu bertempat tinggal di Desa Siaga sehat Jiwa yang pada saat ini baru dibentuk, sehat jasmani rohani, bisa baca tulis, bersedia secara sukarela, memiliki komitmen menjalankan program Desa Siaga Sehat Jiwa dan mendapat izin dari keluarga. KKJ beranggotakan kader yang sebagian besar (70\%) berasal dari kader posyandu, 30\% kader anggota baru berasal anggota karang taruna dan masyarakat. Karakteristik kader yang menjadi anggota KKJ rata-rata berusia 45 tahun, dan data demografi lainnya dapat dilihat pada tabel 1.

Tabel 1.

Karakteristik Kader Kesehatan Jiwa di Desa Siaga Sehat Jiwa Desa Mandalaherang Wilayah Kerja Puskesmas Cimalaka

\begin{tabular}{llcc}
\hline & Karakteristik & Frekuensi & $\%$ \\
\hline \multirow{2}{*}{ Jenis } & Laki-laki & 18 & 26 \\
\cline { 2 - 4 } Kelamin & Perempuan & 52 & 74 \\
\hline Pendidikan & Dasar & 35 & 50 \\
\hline & Menengah & 31 & 44 \\
\hline & Tinggi & 4 & 6 \\
\hline
\end{tabular}

Berdasarkan tabel 1 diatas menunjukan bahwa sebagian besar kader kesehatan jiwa didominasi oleh perempuan yaitu sebanyak $74 \%$ dengan latar belakang pendidikan setengahnya (50\%) adalah pendidikan dasar.

Pembentukan dan keberadaan kader kesehatan jiwa ini sangat diperlukan oleh masyarakat karena dapat membantu proses penyembuhan dan meningkatkan derajat kesehatan jiwa masyarakat. Hal ini sesuai dengan teori menurut Suryani (2018) bahwa kader merupakan factor eksternal yang dapat mendukung keberhasilan pasien ODGJ yang menjalani proses recovery pada tahap penyembuhan dan pemulihan dimasyarakat. Selain itu juga didukung oleh hasil penelitian (Winahayu, Keliat, \& Wardani, 2014) yang mneyatakan bahwa kader merupakan ujung tombak dalam pemberdayaan masyarakat dalam meningkatkan kesehatan jiwa di masyarakat. Hasil penelitian (SAHRIANA, 2018) bahwa kader berperan dalam melaksanakan pencegahan tersier membantu rehabilitasi pasien ODGJ dapat memotivasi minum obat dan untuk secara rutin.

\section{Pelatihan Kader Kesehatan Jiwa}

Evaluasi pelatihan kader kesehatan jiwa dilakukan di akhir pelatihan yaitu mengukur tingkat pengetahuan kader kesehatan jiwa dengan cara membagikan intrumen pertanyaan tentang materi pelatihan yang sudah diberikan. Hasil dari pelatihan kader kesehatan jiwa yang diikuti oleh 70 kader kesehatan jiwa tersebut menunjukan adanya peningkatan pengetahuan kader kesehatan jiwa sebesar 20,71 dengan melihat skor perubahan pada hasil pre 54,20 dan post tes menjadi 75, 21. 


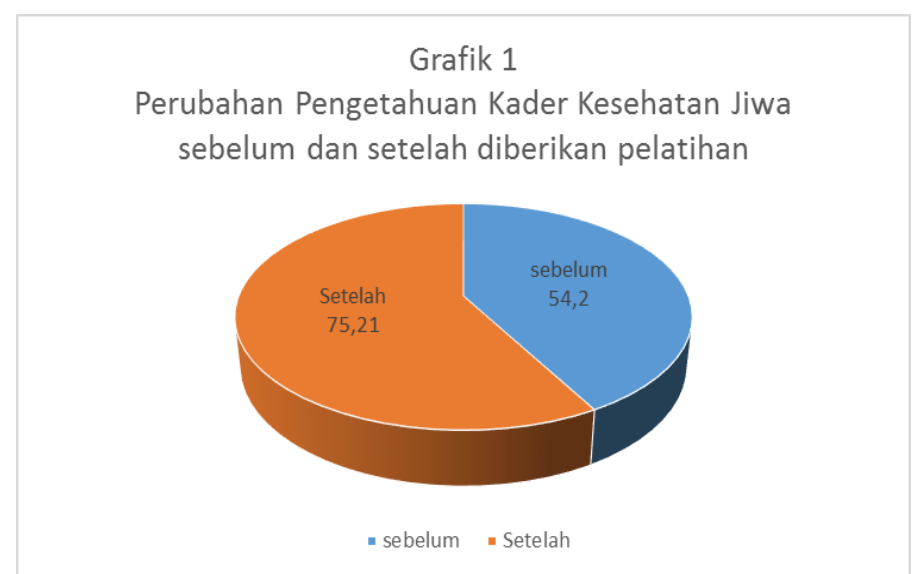

Rata-rata skor hasil evaluasi kemampuan kader dalam melakukan deteksi kesehatan jiwa keluarga setelah dilakukan pelatihan meningkat sebesar 46. Perubahan kemampuan kader dapat dilihat pada diagram 2.

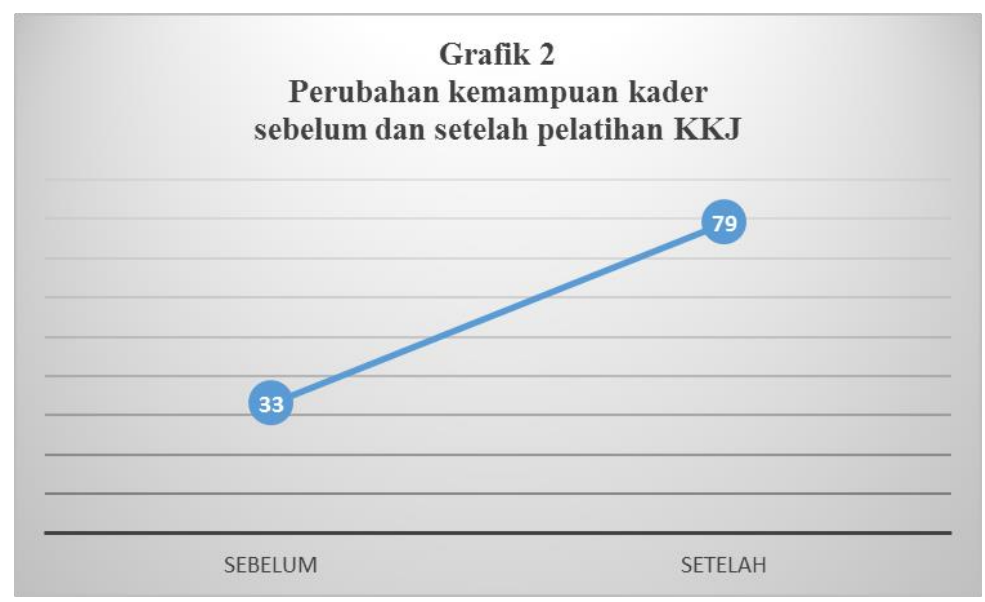

Meningkatnya pengetahuan dan kemampuan kader diharapkan dapat meningkatkan peran dan tanggung jawab kader dalam melaksanakan tugasnya sehingga kesehatan jiwa masyarakat menjadi optimal. Menurut hasil penelitian (Tania, Suryani, \& Hernawaty, 2019) mengatakan bahwa pelatihan kader sangat dibutuhkan sebagai optimalisasi peran kader dalam mendukung proses recovery pasien gangguan jiwa yang ada di lingkungan tempat tinggalnya, sedangkan pengetahuan menjadi faktor penguat kader kesehatan jiwa dalam melaksanakan perannya di mayarakat (SAHRIANA, 2018).

\section{Hasil Deteksi Kesehatan Jiwa Keluarga}

Hasil deteksi kesehatan jiwa keluarga yang dilakukan oleh kader kesehatan jiwa di Desa Siaga Sehat Jiwa Desa Mandalaherang yang terdiri dari 8 RW yang berjumlah 1877 KK dapat dilihat pada grafik 3 dan 4. 


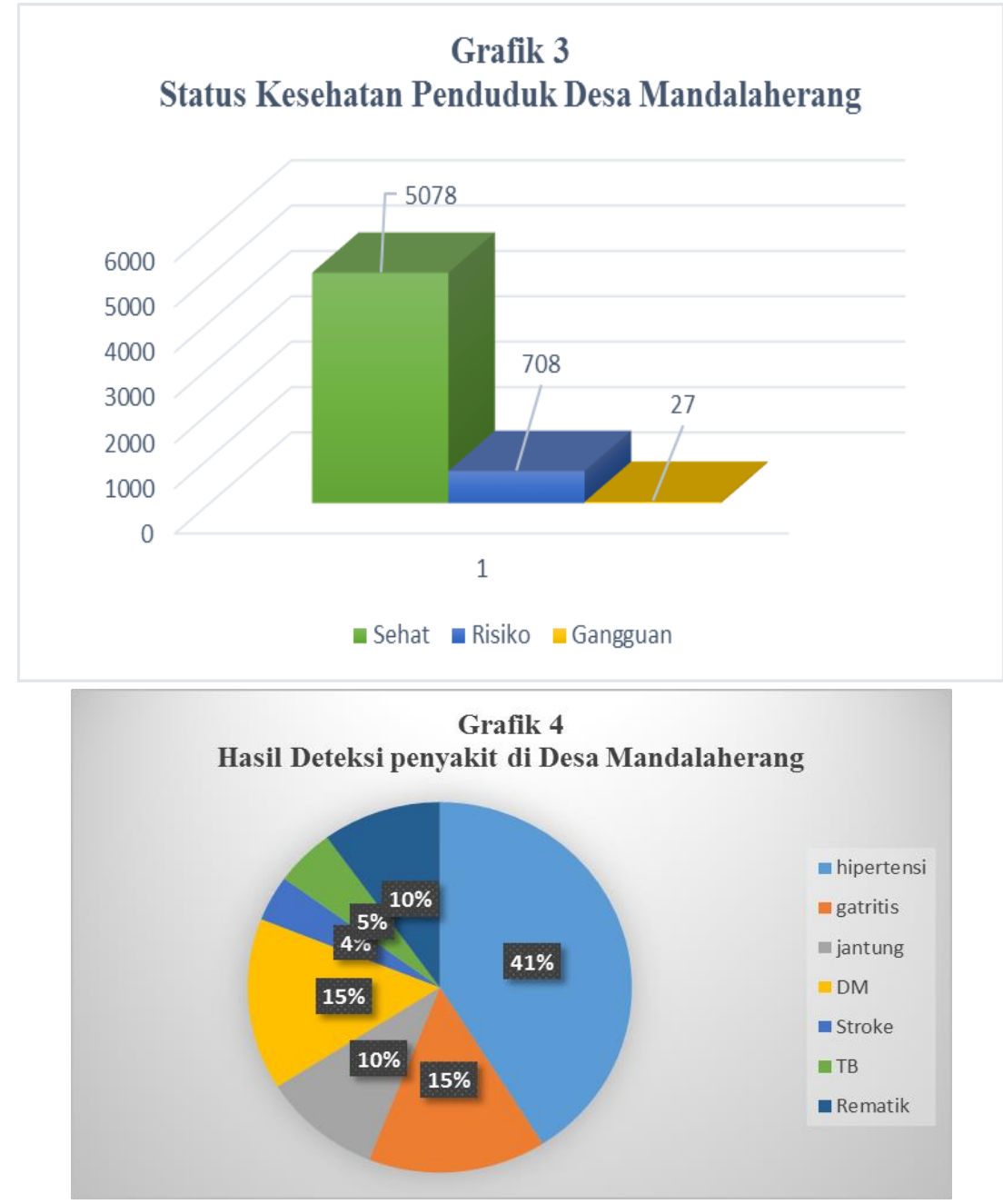

Hasil deteksi diatas menunjukan bahwa status kesehatan masyarakat berada pada kategori sehat, dan hampir setengahnya kelompok risiko mengalami hipertensi serta pada kategori gangguan jiwa mengalami peningkatan sebesar 19 orang yang dari jumlah sebelumnya. Hal ini menunjukan adanya peningkatan pengetahuan dan kesadaran warganya dalam masalah kesehatan jiwa sehingga lebih terbuka untuk mengenal masalah kesehatan jiwa dan harus segera diatasi.

\section{Kesimpulan}

1. Upaya meningkatkan kesehatan jiwa di masyarakat melalui pemberdayaan masyarakat agar masyarakat sadar, mau dan mampu mandiri untuk mengatasi masalah kesehatan jiwa melalui program pembentukan Desa Siaga Sehat Jiwa.

2. Pembentukan Desa Siaga Sehat Jiwa (DSSJ) dan Kader kesehatan jiwa sebagai langkah awal dalam upaya mengatasi masalah kesehatan jiwa di wilayah kerja Puskesmas Cimalaka dan hasil deteksi dapat dijadikan sebagai data dasar untuk menentukan tindakan selanjutnya dan penentuan arah kebijakan pemerintah. 


\section{BIBLIOGRAFI}

Alwasilah, A. C., \& Setiawan, H. (2011). Pokoknya action research. Kiblat Buku Utama.

Cimalaka, P. (2018). Profil Kesehatan Wilayah Kerja Puskesmas Cimalaka. Sumedang: UPTD Dinkes Kabupaten Sumedang.

Fitri, L. D. N. (2007). Hubungan Pelayanan Community Mental Health Nursing (CMHN) dengan Tingkat Kemandirian Pasien Gangguan Jiwa di Kabupaten Bireuen Aceh. Tesis FIK UI. tidak dipublikasikan.

Junardi, J., Keliat, B. A., \& Daulima, N. H. C. (2017). Analisis Faktor-Faktor Yang Berhubungan Dengan Keberhasilan Pelaksanaan Kegiatan Community Mental Health Nursing Di Aceh. Idea Nursing Journal, 8(1), 1-11.

Keliat, B A, Panjaitan, R. U., Riasmini, M., \& Mardella, E. (2010). A.(2010). Model Praktik Keperawatan Profesional Jiwa. Jakarta: Penerbit Buku Kedokteran EGC.

Keliat, Budi Anna, Helena, N., \& Nurhaeni, H. (2011). Keperawatan kesehatan jiwa komunitas. EGC.

Keliat, Budi Anna, Panjaitan, R. U., \& Riasmini, M. (2011). Manajemen Keperawatan Jiwa Komunitas Desa Siaga. EGC.

Kesehatan, B. P. dan P. (2013). Riset Kesehatan Dasar. Jakarta: Kemenkes RI.

Pujiastuti, E. (2017). Hubungan Antara Kompetensi Profesional Tenaga Medis, Budaya Kerja Dan Gaya Kepemimpinan Dengan Mutu Pelayanan Pasien Rawat Inap Di Rumah Sakit Waled Kab. Cirebon. Syntax Literate; Jurnal Ilmiah Indonesia, 2(4), 34-65.

Sahriana, N. I. M. (2018). Peran Kader Kesehatan Jiwa Dalam Program Kesehatan Jiwa Komunitas Di Masyarakat. Universitas Airlangga.

Stuart, G. W. (2014). Principles and practice of psychiatric nursing-e-book. Elsevier Health Sciences.

Tania, M., Suryani, S., \& Hernawaty, T. (2019). Pengalaman Hidup Kader Kesehatan dalam Mendukung Proses Recovery di Melong Kota Cimahi. Jurnal Keperawatan BSI, 7(1).

Townsend, M. C., \& Morgan, K. I. (2017). Psychiatric mental health nursing: Concepts of care in evidence-based practice. FA Davis.

Winahayu, N. E., Keliat, B. A., \& Wardani, I. Y. (2014). Faktor sustainability yang berhubungan dengan implementasi community mental health nursing (CMHN). Jurnal Ners, 9, 305-312. 